\title{
Waterpipe tobacco smoking impact on public health: implications for policy
}

This article was published in the following Dove Press journal:

Risk Management and Healthcare Policy

27 August 2015

Number of times this article has been viewed

\section{Mary P Martinasek' \\ Linda M Gibson-Young ${ }^{2}$ \\ Janiece N Davis ${ }^{3}$ \\ Robert J McDermott ${ }^{4}$}

'Public Health Department of Health Sciences and Human Performance, University of Tampa, Kennedy Boulevard, Tampa, FL, ${ }^{2}$ College of Nursing and Health Sciences, Texas A\&M University: Corpus Christi, Corpus Christi, TX, ${ }^{3}$ Department of Health - Palm Beach County, West Palm beach, FL, ${ }^{4}$ Department of Population Health Sciences, School of Medicine and Public Health, University of Wisconsin-Madison, Madison, WI, USA
Correspondence: Mary P Martinasek Public Health Department of Health Sciences and Human Performance, University of Tampa, 40I West Kennedy Boulevard, Box 30F, Tampa,

FL 33606, USA

Tel + I 8I32575037

Emailmmartinasek@ut.edu
Background: Given the increasing evidence of its negative health effects, including contributions to both infectious and chronic diseases, waterpipe tobacco smoking raises public health concerns beyond even those presented by traditional smoking.

Methods: Identification of Clean Indoor Air Acts (CIAAs) from each of the 50 United States and District of Columbia were retrieved and examined for inclusion of regulatory measures where waterpipe tobacco smoking is concerned. Several instances of exemption to current CIAAs policies were identified. The cumulative policy lens is presented in this study.

Results: States vary in their inclusion of explicit wording regarding CIAAs to the point where waterpipe tobacco smoking, unlike traditional smoking products, is excluded from some legislation, thereby limiting authorities' ability to carry out enforcement.

Conclusion: Consistent, comprehensive, and unambiguous legislative language is necessary to prevent establishments where waterpipe tobacco smoking occurs from skirting legislation and other forms of regulatory control. Stricter laws are needed due to the increasing negative health impact on both the smoker and the bystander. Actions at both the federal and state levels may be needed to control health risks, particularly among youth and young adult populations.

Keywords: health policy, waterpipe tobacco, hookah smoking, tobacco regulation

\section{Introduction}

More than a decade ago, tobacco smoking was identified as the leading actual cause of death and disease in the US. ${ }^{1}$ In the US, tobacco smoking occurs with traditional cigarettes, cigars, pipes, and more novel devices called hookahs or waterpipes. In other parts of the world, these alternative methods may be referred to as hubble-bubble, nargeela, nargileh, argeela, arghileh, okka, kalian, ghelyoon, ghalyan, boury, or gouza. ${ }^{2}$ Waterpipe tobacco smoking is a form of social smoking that involves smoking flavored tobacco called "shisha" or "ma'ssell." Shisha most often comes flavored in attractive packages laden with colorful and esthetically pleasing pictures that foster its appeal. The US tobacco companies produce more shisha than ever before, and its sales account for an increasing proportion of tobacco revenue. The waterpipe device consists of a clay pot that holds the foil-covered shisha over a glass bowl of water at the base through which the smoke bubbles before entering a plastic hose and mouthpiece where the smoker inhales. Charcoal is lit on top of the perforated foil-covered shisha and serves as the heating element for "baking" the shisha. Shisha is then vaporized and passed through the water basin in the form of smoke. A typical waterpipe tobacco session may last $\sim 45$ minutes and involves socialization among a number of individuals who share a hose and pipe. 
Waterpipe smoking has an extensive history and originated in India over 400 years ago. ${ }^{3}$ Over the past 20 years, a revival of waterpipe usage occurred and spread from northern Africa and Southeast Asia to Europe and North America. The lack of knowledge concerning negative health effects of waterpipe tobacco smoking may have contributed to the spread of use, as well as the popularity of flavored tobacco. ${ }^{4,5}$ This revival has led to increased use among youth and young adult populations statewide and nationally, ${ }^{6-8}$ where prevalence rates range from $15 \%$ to $48 \% .^{9-12}$ From 2011 to 2014, waterpipe tobacco use doubled, ${ }^{12}$ accompanied by corresponding public health concerns.

From an acute health perspective, there exist concerns related to infectious disease transmission. This concern is novel to waterpipe tobacco smoking as opposed to traditional smoking because of the sharing or passing around of a common mouthpiece in waterpipe smoking. Infectious disease transmission is likely due to the sharing of mouthpieces that currently lack device-cleaning regulations within waterpipe smoking establishments. Concerns of infectious diseases leading to respiratory illness are legitimate due to waterpipes being a warm medium for the growth of bacteria. According to Safizadeh et al: ${ }^{13}$

Of 285 samples from different parts of the waterpipes, 236 (82.8\%) showed positive cultures; the rate of contamination ranged from $69 \%$ in the fixed mouthpiece to $96 \%$ in bowl water.

Both Gram-positive and Gram-negative isolates have been cultured from waterpipes with the majority being Micrococcus, Corynebacterium, and Bacillus. ${ }^{4}$ Streptococcus is the most common bacterial agent in community-acquired pneumonias. ${ }^{14}$ Additionally, aspergillosis and tuberculosis have been linked to waterpipe smoking. ${ }^{15,16}$ There could be transmission of other pathogens, including hepatitis $\mathrm{C}$, herpes simplex, and Epstein-Barr virus. ${ }^{17}$

Emissions from the burning charcoal may affect not only the smoker but also workers in waterpipe smoking establishments and other patrons who may not be smoking waterpipe tobacco directly. The charcoal produces heavy metals and carbon monoxide $(\mathrm{CO})$ that are inhaled by the smoker. ${ }^{18,19}$ $\mathrm{CO}$ is a specific concern with respect to waterpipe tobacco smoking (with or without tobacco) because of the high levels in which it is present. ${ }^{20-22}$ High CO levels arise from charcoal combustion, and some reports suggest that the $\mathrm{CO}$ can be 30 times higher for waterpipe smokers than for cigarette smokers. ${ }^{23}$ At least six cases of $\mathrm{CO}$ poisoning as a consequence of waterpipe tobacco smoking have been documented with carboxyhemoglobin levels in the range of $20 \%-30 \% .{ }^{24}$ Carbon monoxide has the ability to replace oxygen-binding sites in the body and impair oxygen delivery to the tissues. Emergency room visits document cases of carbon monoxide toxicity that have required several hours of care and provision of oxygen and other health care services. ${ }^{25}$ Furthermore, tests on patrons exiting waterpipe smoking establishments demonstrate that they have elevated levels of carbon monoxide. ${ }^{21,22}$

In addition to these fairly immediate consequences, waterpipe tobacco smoking has been associated with chronic diseases. Smoke from a waterpipe contains carcinogens from the aldehyde groups such as formaldehyde and acetaldehyde and, compared with factory-made cigarettes, significant amounts of polycyclic aromatic hydrocarbons (PAHs), notably benzo[a]pyrene. ${ }^{23}$ PAHs act both as tumor initiators and co-carcinogens. ${ }^{26}$ For instance, they have been linked to lung cancer and lip cancer. ${ }^{27-29}$ Additional chronic conditions related to cardiovascular disease and pulmonary function changes exist among waterpipe tobacco smokers. ${ }^{30,31}$

These health risks notwithstanding, youth and young adults perceive waterpipe use as less harmful than cigarette smoking, and this perception can lead to an increased social acceptance. ${ }^{32}$ Other reasons for smoking waterpipe tobacco include relaxation, pleasure, and entertainment. ${ }^{33}$ Myslin et $\mathrm{al}^{34}$ found hookah-related messages (ie, tweets) via social media were predominantly positive in nature (unlike tweets about more traditional tobacco products) and reflected constructs they categorized as representing sociability, pleasure, and favorable social image. Waterpipe tobacco smoking is most prevalent in the 18-24-year-old age group and in regions where smoke-free legislation is well established and smoking traditional cigarettes has declined. ${ }^{35}$ Consequently, representations employing social media may encourage people in this age group to try waterpipe tobacco smoking. An additional research supports the claim that waterpipe's marketing places it in a much more positive light than cigarettes, adding further to its allure. ${ }^{36}$

Creamer et $\mathrm{al}^{37}$ reported that use of non-cigarette products among high-school-aged youth coupled with concurrent use of traditional tobacco products may be on the rise. If their estimates of dual use are accurate, such a development should raise additional concerns about tobacco's never-ending health burden. An additional evidence from Jamil et $\mathrm{l}^{38}$ showed waterpipe smoking occurred in $19 \%$ of their sample of Michigan adults: 10\% hookah only and $9 \%$ hookah plus cigarettes; moreover, nearly one in five survey 
respondents believed hookah smoking was less harmful than smoking cigarettes. Given what is known about infectious acute diseases, environmental impact, and chronic disease issues related to waterpipe tobacco smoking, it is essential for public health advocates to initiate emphatic discussion on how best to inform policy to include control of waterpipe tobacco smoking.

\section{Policy for waterpipe tobacco smoking use}

Concerted efforts to educate the public about the negative effects of traditional cigarette smoking and to deter this behavior have made significant progress over the past several decades, so much so that the norm is clearly in the direction of not smoking. The concern of secondhand smoke exposure is now understood by the public and was highlighted in the Surgeon General's Report on smoking and health. ${ }^{39}$ Awareness and concern not only for the health of smokers but also those exposed to secondhand smoke have led to an increase in smoking restrictions from standalone organizations to state enactments. In 2014, as an extension to the 2009 Family Smoking Prevention and Tobacco Control Act, the US Food and Drug Administration (FDA) proposed to extend its regulatory capacity to additional tobacco products. Hookah or waterpipe tobacco will be subject to the FDA regulations that include registering with the FDA and reporting ingredients, having the FDA review new products, requiring claims of reduced risk and public health benefit be confirmed by scientific evidence, and prohibiting the distribution of free samples. $^{40}$

Compared with traditional smoking, waterpipe tobacco smoking is a relatively novel form of smoking. In the US, its popularity has been primarily among youth and young adults. ${ }^{35}$ The Centers for Disease Control and Prevention has indicated an increase in waterpipe smoking among US young adults. ${ }^{41}$ Despite the increase in waterpipe smoking, there has been a dearth of educational material and campaigns focused on deterring the behavior. The World Health Organization (WHO) Framework Convention of Tobacco Control stresses the importance of education of harm, clear package content labeling, and prohibition of waterpipe tobacco smoking in areas where cigarettes are banned. The WHO recommends that "education ... is urgently needed about the risks of waterpipe smoking, including high potential levels of secondhand exposure." Moreover, "waterpipe smokers and second-hand smokers [are] at risks for the same kinds of disease as are caused by cigarette smoking, including cancer, heart disease, respiratory disease, and adverse effects during pregnancy." 42
Given the scientific evidence of harmfulness obtained over the past several decades surrounding tobacco use and secondhand smoke, there is an increasing number of states instituting rules and regulations to support and expand existing clean indoor air laws and legislation that include waterpipe smoking establishments.

In this study, we conduct a policy review of current clean indoor air act (CIAA) legislation at the state level, as well as identify legislation pertaining specifically to waterpipe tobacco smoking. To complete this review, we examine stateby-state policy with waterpipe use and allowable exposure. This review provides valuable information for current legislative initiatives and has implications for needed future waterpipe tobacco smoking policy. ${ }^{43}$ In particular, we address the following research questions.

1. Does the state have a CIAA?

2. If the state has a CIAA, is waterpipe tobacco smoking clearly included?

3. If the state has a CIAA, is waterpipe tobacco smoking clearly exempt?

4. Does the CIAA define retail tobacco store or tobacco specialty retail store? If yes, is hookah/waterpipe establishment included in this definition?

5. Is there a connection between prevalence rates and policy?

\section{Methods}

Our review of CIAA legislation and waterpipe tobacco policy inclusion accessed the official websites for both the state legislatures and the departments of (public) health for each state. These websites were examined to assess the existence/nonexistence of a state CIAA. Examination of websites took place from September 2014 to April 2015. We explored waterpipe tobacco exemptions and waterpipe policy options that promote smoke-free environments and decreased use of waterpipes in restaurant settings. Despite the increase in waterpipe tobacco use among young adult and college-aged youth and the concomitant environmental exposure to the contaminants of smoke, businesses often circumvent the CIAA.

The statute of each state and the information pertaining to the research questions, as well as additional information (such as the definition of tobacco per state statute and whether or not hookah, shisha, and waterpipe are included), were prepared in the policy overview tables. In addition to the state CIAAs, information from other regulating agencies such as the departments of business and professional regulation was reviewed to determine if these separate entities 
regulated waterpipe establishment licensing in the absence of state regulations. We searched LexisNexis to verify state legislation in the event that it could not be found on either the state legislature or public health website. Two researchers independently confirmed any updates from the initial policy search and confirmed current information. A summary is provided in Table 1 . The Supplementary materials contains a detailed version of state findings.

\section{Results}

\section{Evidence of clean indoor air legislation}

There is much variability in legislation across the US pertaining to smoking restrictions. However, all US states have some form of a CIAA with the exceptions of West Virginia and Wyoming. Eight states (Alabama, Alaska, Kentucky, Mississippi, Missouri, Oklahoma, South Carolina, and Texas) have CIAAs that pertain only to government-owned buildings and property. This leaves legislation at the local level void of preemption and subject to organizational policy.

\section{Definition of smoking}

Definitions of the act of smoking vary from state to state, with simple references such as "burning" or "puffing" or "possession" to more detailed ones such as "inhaling, exhaling, burning, carrying, or holding." All states with definitions refer to a "lighted" device with device details varying from state to state. Nine states (Alaska, California, Nevada, Oregon, Oklahoma, South Carolina, South Dakota, Texas, and Vermont) have a CIAA in place but do not define the act of smoking. Oklahoma law describes smoke and secondhand smoke but not the explicit act of smoking itself, and Vermont includes "intention" in the device description. Additionally, three states (Alaska, Nevada, and South Carolina) do not identify the devices. With novel devices and products constantly being developed, it becomes challenging for legislation verbiage to be all-inclusive of delivery devices and mechanisms.

\section{Waterpipe tobacco prevalence}

Findings from the National Adult Tobacco Survey indicate that the four states with the highest prevalence of waterpipe tobacco smoking ever-use are Nevada, California, Colorado, and New Mexico. ${ }^{35}$ However, ever-use in the District of Columbia exceeds all four of these states, and waterpipe lounges are not mentioned directly in the law. ${ }^{35}$ California, Oregon, and Nevada do not define smoking in their legislation. New Mexico has exemptions for waterpipe establishments. The lowest rates of ever-use of waterpipe tobacco smoking were found in West Virginia, where there is no CIAA, as well as in Alabama, North Dakota, Mississippi, South Carolina, and Nebraska.

\section{Device and product smoked}

Although some states mention "pipe tobacco" in their CIAAs, this language becomes subject to interpretation as do the actual devices that burn waterpipe tobacco. For instance, newer devices are being used to smoke waterpipe tobacco that deviate from the traditional water bowl and pipe designs. If legislation neither refers specifically to tobacco nor to waterpipe tobacco, then the legislation is subject to interpretation. Additionally, there are waterpipe establishments that sell tea leaves and other nontobacco products. Although these leaves do not contain tobacco, they are fraught with carcinogens, if smoked, as well as an ability to generate carbon monoxide. ${ }^{95}$ States have legislation verbiage that may help to cover these types of issues by listing “... other lighted combustible plant material" similar to the CIAA definition provided by Arkansas, Minnesota, Hawaii, and Louisiana. New Jersey legislation makes the definition even more far reaching by stating "any other matter that can be smoked", and North Dakota states “... or plant product intended for inhalation, in any manner or in any form."

Another option for policymakers to cover devices and products is seen in Illinois legislation that declares "... or any other lighted smoking equipment." This particular choice of language implies an assumption that future devices will require lighting. Waterpipe tobacco smoking in particular has avoided legislation that included the burning of tobacco because with the traditional waterpipe devices, the charcoal that sits atop the foil-covered tobacco is lit rather than the waterpipe tobacco itself.

\section{Waterpipe tobacco inclusion in CIAA definition}

Specific wording in the CIAA state definitions is lacking. There are only a few states that mention the word hookah or waterpipe. Utah includes "hookah" as part of its definition in the CIAA stating "cigar, cigarette, pipe, or hookah," and Maine includes "other object giving off tobacco smoke" in its definition and further goes on to define waterpipe or hookah. Connecticut includes "waterpipe, hookah, or similar device" in its legislative definition. Importance in describing the nature of the smoking, the product being smoked, and the delivery device as broadly as possible may enable legislation to be responsive, effective, and long-lasting as new products (eg, e-cigarettes) are introduced to the marketplace. 
Table I Summary of waterpipe regulation or exemption mentioned in the CIAA or other state statute

\begin{tabular}{|c|c|c|c|c|}
\hline State name & $\begin{array}{l}\text { Explicit definition } \\
\text { of smoking per } \\
\text { state's CIAA }\end{array}$ & $\begin{array}{l}\text { Retail tobacco store/tobacco } \\
\text { specialty retail store definition } \\
\text { per state's CIAA or other state } \\
\text { statute }\end{array}$ & $\begin{array}{l}\text { Retail tobacco storel } \\
\text { tobacco specialty retail } \\
\text { store exemption }\end{array}$ & $\begin{array}{l}\text { Waterpipe Regulation } \\
\text { or Exemption } \\
\text { Mentioned in the CIAA } \\
\text { or other State Statute }\end{array}$ \\
\hline Alabama $^{44}$ & Yes & No but with contingency & Yes & No but with contingency \\
\hline Alaska $^{45}$ & No & No but with contingency & No & No but with contingency \\
\hline Arizona $^{46}$ & Yes & Yes & Yes & No but with contingency \\
\hline Arkansas ${ }^{47}$ & Yes & Yes & Yes & No but with contingency \\
\hline California $^{48}$ & No & Yes & No but with contingency & No but with contingency \\
\hline Colorado ${ }^{49}$ & Yes & Yes & Yes & No but with contingency \\
\hline Connecticut $^{50}$ & Yes & Yes & Yes & Yes \\
\hline Delaware ${ }^{51}$ & Yes & Yes & No but with contingency & No \\
\hline District of Columbia ${ }^{52}$ & Yes & Yes & Yes & No but with contingency \\
\hline Florida $^{53}$ & Yes & Yes & Yes & Yes \\
\hline Georgia $^{54}$ & Yes & Yes & Yes & No but with contingency \\
\hline Hawaii 55 & Yes & Yes & Yes & No but with contingency \\
\hline Idaho ${ }^{56}$ & Yes & No but with contingency & Yes & Yes \\
\hline Illinois ${ }^{57}$ & Yes & Yes & Yes & Yes \\
\hline Indiana ${ }^{58}$ & Yes & Yes & Yes & Yes \\
\hline lowa ${ }^{59}$ & Yes & Yes & Yes & No but with contingency \\
\hline Kansas $^{60}$ & Yes & Yes & Yes & No but with contingency \\
\hline Kentucky ${ }^{61}$ & No & Yes & Yes & No \\
\hline Louisiana $^{62}$ & Yes & Yes & Yes & No \\
\hline Maine ${ }^{63}$ & Yes & Yes & Yes & Yes \\
\hline Maryland ${ }^{64}$ & Yes & Yes & Yes & Yes \\
\hline Massachusetts ${ }^{65}$ & Yes & Yes & Yes & No but with contingency \\
\hline Michigan $^{66}$ & Yes & Yes & Yes & Yes \\
\hline Minnesota $^{67}$ & Yes & Yes & Yes & No \\
\hline Mississippi ${ }^{68}$ & Yes & No & No but with contingencies & No but with contingency \\
\hline Missouri69 & Yes & No & Yes & No \\
\hline Montana $^{70}$ & Yes & Yes & No & No \\
\hline Nebraska $^{71}$ & Yes & Yes & Yes & No \\
\hline $\mathrm{Nevada}^{72}$ & No & Yes & Yes & No but with contingency \\
\hline New Hampshire ${ }^{73}$ & Yes & Yes & No but with contingency & No \\
\hline New Jersey ${ }^{74}$ & Yes & Yes & Yes & \\
\hline New Mexico ${ }^{75}$ & Yes & Yes & Yes & \\
\hline New York ${ }^{76}$ & Yes & Yes & Yes & \\
\hline North Carolina ${ }^{77}$ & Yes & Yes & Yes & No but with contingency \\
\hline North Dakota ${ }^{78}$ & Yes & No but with contingency & No & Yes \\
\hline Ohio $^{79}$ & Yes & Yes & Yes & No but with contingency \\
\hline Oklahoma $^{80}$ & Yes & No & Yes & No but with contingency \\
\hline Oregon $^{81}$ & No & Yes & Yes & No but with contingency \\
\hline Pennsylvania $^{82}$ & Yes & Yes & Yes & Yes \\
\hline Rhode Island ${ }^{83}$ & Yes & Yes & Yes & Yes \\
\hline South Carolina ${ }^{84}$ & No & No & Yes & Yes \\
\hline South Dakota ${ }^{85}$ & No & Yes & Yes & Yes \\
\hline Tennessee $^{86}$ & Yes & Yes & Yes & No but with contingency \\
\hline Texas $^{87}$ & No & Yes & Yes & Yes \\
\hline$U \operatorname{tah}^{88}$ & Yes & No & Yes & Yes \\
\hline Vermont ${ }^{89}$ & Yes & Yes & No & No \\
\hline Virginia $^{90}$ & Yes & No & Yes & Yes \\
\hline Washington ${ }^{91}$ & Yes & Yes & No & No but with contingency \\
\hline West Virginia ${ }^{92}$ & No & No but with contingency & No & No \\
\hline Wisconsin ${ }^{93}$ & Yes & Yes & No but with contingency & Yes \\
\hline Wyoming ${ }^{94}$ & No & Yes & No & No \\
\hline
\end{tabular}

Abbreviation: CIAA, Clean Indoor Air Act. 


\section{Exemptions}

Although tobacco products may be included in legislative definitions, waterpipe establishments have become exempt from CIAAs based on their being structured as tobacco business/retail stores. Depending on the interpretation of the law and the structure of the business, 24 states have an exemption for waterpipe establishments: Alabama, Alaska, Arkansas, Colorado, Georgia, Hawaii, Idaho, Iowa, Louisiana, Florida, Maryland, Massachusetts, New York, North Carolina, New Mexico, Nebraska, Nevada, Ohio, Oklahoma, Oregon, Pennsylvania, Rhode Island, and Tennessee. Utah has exemptions but only for waterpipe smoking establishments with a sunset date of July 2017. Exemption of waterpipe tobacco use in these states allows waterpipe usage where smoking or tobacco usage is banned.

Another 14 states have a "percentage of sales requirement" for tobacco products, thereby enabling waterpipe smoking establishment exemption to occur; moreover, this percentage varies considerably from state to state. These states and their respective sales requirements are Arizona (51\%), California $(60 \%)$, Connecticut $(10 \%)$, Illinois $(80 \%)$, Indiana (85\%), Kansas (65\%), Maine (60\%), Michigan (75\%), Minnesota (90\%), Missouri (50\%), New Jersey (51\%), North Carolina (75\%), South Dakota (65\%), and Wisconsin (75\%). Consequently, marketing waterpipe smoking is proving beneficial for some establishments in certain states. It is unclear if the District of Columbia and Alaska have exemptions in place for waterpipe smoking establishments. Clearly, the existing legislation in more than half of the states has the potential to exempt waterpipe smoking establishments from their CIAA.

Other states such as South Carolina, Texas, and Vermont do not list tobacco stores as public places that are included in their CIAA; therefore, they may be exempt. Delaware, New Hampshire, North Dakota, Montana, and Vermont are the only states that have a CIAA and do not have visible exemption loopholes. Washington has no exemption for tobacco retail stores.

\section{Discussion}

Clean air indoor laws have been instituted around the USA to improve air quality for the good of the public's health. Increasing scientific evidence has provided information that waterpipe smoking is not a safe alternative to traditional cigarette smoking and carries many secondhand risks similar to ones pertaining to traditional cigarette smoking. ${ }^{96}$ The WHO recommends that "waterpipes should be prohibited in public places consistent with bans on cigarette and other forms of tobacco smoking." ${ }^{\prime 2}$ Such recommendations notwithstanding, not all US states have adopted a CIAA and clearly not all venues are covered under some regulatory actions. Increasingly, however, smoke-free indoor air ordinances are being proposed and implemented.

Direct exposure to waterpipe smoking contributes to selected infectious diseases and certain chronic conditions; moreover, the effects of secondhand smoke exposure contribute to or exacerbate some chronic diseases, especially ones of a respiratory nature. ${ }^{97}$ Exposures to both the smoker and bystander have significant implications for CIAA legislation. Following are identified points in effectively developing waterpipe tobacco legislation:

1. Tighten up policies to disallow waterpipe establishment loopholes and exemptions

2. Clear wording in statewide policies to include tobacco smoked using waterpipes

3. Regulations on packaging contents for consumers

4. Information on negative health effects on packaging

5. Elimination of packaging that contains luring fruit pictures

6. Information on known negative health effects displayed in waterpipe establishments

7. FDA regulations on secondhand smoke exposure from waterpipe tobacco smoking

8. Regulation on cleaning of waterpipes in bars/cafes/ restaurants

9. Occupational Safety and Health Administration regulation on air quality of waterpipe establishments for workers.

Policy can have a broad impact on reduction of rates of smoking when it manifests with clear and unambiguous regulatory language. Waterpipe tobacco smoking establishments, as well as tobacco shops, have managed to avoid state clean indoor air laws that are not inclusive of specific and unambiguous language. A legal concern related to waterpipe tobacco smoking is whether or not it is included in CIAA legislation. ${ }^{98}$ Some states exempt waterpipe smoking establishments from the CIAA, whereas others include waterpipe tobacco smoking verbiage specifically. Oregon, for example, experienced negative effects in tobacco control program costs and diversion from their evidence-based programmatic focus by lacking clear definitions of "sampling" and waterpipe tobacco shops being included under the umbrella of a smoke shop..$^{99}$ Whether current state-wide legislation effectively covers waterpipe smoking establishments is subject to interpretation. Overarching federal legislation would serve to minimize loopholes and maintain consistency across all states. Federal legislation would have a broader impact of protecting the public's health from this known danger. 


\section{Conclusion}

Smoke-free environments not only protect people from secondhand smoke exposure but also increase the normative behavior of not smoking. By doing so, cessation is promoted and youth and young adults may be less inclined to partake in waterpipe tobacco smoking. Waterpipe smoking establishments encourage a community social norm and a perception of acceptance. ${ }^{100}$ Our study findings demonstrate that waterpipe tobacco smoking regulatory control in many venues is misaligned with the evidence base regarding the disease effects of waterpipe smoking for both users and the non-users who share the waterpipe smoking environment. Few states actually identify waterpipe smoking use as a health hazard. Public health advocates must be vigilant with waterpipe tobacco smoking, its various delivery mechanisms, as well as other emerging tobacco-related devices. Current policies appear to be ineffective at limiting or discouraging waterpipe "ever-use" among $18-24$-year-olds, ${ }^{35}$ the most vulnerable age group in the US for the uptake of waterpipe tobacco smoking. Future studies should examine state-to-state prevalence of waterpipe smoking establishments, particularly ones occupying areas in proximity to colleges and universities, to determine the relationship between waterpipe tobacco smoking in this population and placement of these establishments.

\section{Acknowledgments}

We acknowledge the work of two public health students Jamie McGrogan and Alisha Maysonet for their devoted efforts in reviewing and updating the policy table.

\section{Disclosure}

The authors report no conflicts of interest in this work.

\section{References}

1. Mokdad AH, Marks JS, Stroup DF, Gerberding JL. Actual causes of death in the United States, 2000. JAMA. 2004;291(10):1238-1245.

2. Aljarrah K, Ababneh Z, Al-Delaimy W. Perceptions of hookah smoking harmfulness: predictors and characteristics among current hookah users. Tob Induc Dis. 2009;5(16):1-7.

3. Ray C. The hookah - the Indian waterpipe. Curr Sci. 2009;96(10): 1319-1323.

4. Masadeh MM, Hussein EI, Alzoubi KH, Khabour O, Skakhatreh MA, Gharaibeh M. Identification, characterization and antibiotic resistance of bacterial isolates obtained from waterpipe device hoses. Int J Environ Res Public Health. 2015;12(5):5108-5115.

5. Rastam S, Ward KD, Eissenberg T, Maziak W. Estimating the beginning of the waterpipe epidemic in Syria. BMC Public Health. 2004;4:32.

6. Cavazos-Regq PA, Krauss MJ, Kim Y, Emery SL. Risk factors associated with hookah use. Nicotine Tob Res. Epub 2015 Feb 2.

7. Maziak W, Ward KD, Eissenberg T. Interventions for waterpipe smoking cessation. Cochrane Database Syst Rev. 2007;4:CD005549.

8. Barnett TE, Forrest JR, Porter L, Curbow BA. A multiyear assessment of hookah use prevalence among Florida high school students. Nicotine Tob Res. 2014;16(3):373-377.
9. Eissenberg T, Ward KD, Smith-Simone S, Maziak W. Waterpipe tobacco smoking on a US College campus: prevalence and correlates. J Adolesc Health. 2008;42(5):526-529.

10. Smith SY, Curbow B, Stillman FA. Harm perception of nicotine products in college freshmen. Nicotine Tob Res. 2007;9(9):977-982.

11. Primack BA, Sidani J, Agarwal AA, Shadel WG, Donny EC, Eissenberg TE. Prevalence of and associations with waterpipe tobacco smoking among US university students. Ann Behav Med. 2008;36(1):81-86.

12. Smith-Simone S, Curbow B, Stillman F. Differing psychosocial risk profiles of college freshmen waterpipe, cigar, and cigarette smokers. Addict Behav. 2008;33(12):1619-1624.

13. Safizadeh H, Moradi M, Rad MR, Nakhaee N. Bacterial contamination of different components of the waterpipe. Int J Tuberc Lung Dis. 2014;18:988-991.

14. Purushothama V, Liu D, Liu C. Infections of the respiratory system. In: Baron S, editor. Medical Microbiology. 4th ed. Galveston, TX: University of Texas Medical Branch; 1996. Chapter 93. Available from: http:// www.ncbi.nlm.nih.gov/books/NBK8142. Accessed August 12, 2015.

15. Munckhof WJ, Konstantinos A, Wamsley M, Mortlock M, Gilpin C. A cluster of tuberculosis associated with use of marijuana water pipe. J Tuberc Lung Dis. 2003;7:860-865.

16. Szyper-Kravitz M, Lang R, Manor Y, Lahav M. Early invasive pulmonary aspergillosis in a leukemia patient linked to aspergillus contaminated marijuana smoking. Leuk Lymphoma. 2001;42:1433-1437.

17. Knishkowy B, Amitai Y. Water-pipe (narghile) smoking: an emerging health risk behavior. Pediatrics. 2005;116(1):e113-e119.

18. Shihadeh A. Investigation of mainstream smoke aerosol of the argileh water pipe. Food Chem Toxicol. 2003;41(1):143-152.

19. Sepetdjian E, Shihadeh A, Saliba NA. Measurement of 16 polycyclic aromatic hydrocarbons in narghile waterpipe tobacco smoke. Food Chem Toxicol. 2008;46(5):1582-1590.

20. Shafagoj Y, Mohammed F. Levels of maximum end-expiratory carbon monoxide and certain cardiovascular parameters following hubblebubble smoking. Saudi Med J. 2002;23(8):953-958.

21. Barnett TE, Curbow BA, Soule EK Jr, Tomar SL, Thombs DL. Carbon monoxide levels among patrons of hookah cafes. Am J Prev Med. 2011; 40(3):324-328.

22. Martinasek M, Ward K, Calvanese A. Change in carbon monoxide exposure among waterpipe bar patrons. Nicotine Tob Res. 2014;16(7) 1014-1019.

23. Shubert J, Hahn J, Dettbarn G, Seidel A, Luch A, Schulz TG. Mainstream smoke of the waterpipe: does this environmental matrix reveal as significant source of toxic compounds? Toxicol Lett. 2011;205(3): 279-284.

24. La Fauci G, Weiser G, Steiner IP, Savit I. Carbon monoxide poisoning in narghile (water pipe) tobacco smokers. CJEM. 2012;14(1):57-59.

25. Clarke SF, Stephens C, Farhan M, et al. Multiple patients with carbon monoxide toxicity from water-pipe smoking. Prehosp Disaster Med. 2012;27(6):612-614.

26. Shihadeh A, Saleh R. Polycyclic aromatic hydrocarbons, carbon monoxide, "tar," and nicotine in the mainstream smoke aerosol of the narghile water pipe. Food Chem Toxicol. 2005;43(5):655-661.

27. Gupta D, Boffetta P, Gaborieau V, Jindal S. Risk factors of lung cancer in Chandigarh, India. Indian J Med Res. 2001;113:142-150.

28. Nafae A, Misra SP, Dhar SN, Shah SN. Bronchogenic carcinoma in Kashmir Valley. Indian J Chest Dis. 1973;15:285-295.

29. El-Hakim IE, Uthman MA. Squamous cell carcinoma and keratoacanthoma of the lower lip associated with "Goza" and "Shisha" smoking. Int J Dermatol. 1999;38(2):108-110.

30. Jabbour S, El-Roueiheb Z, Sibai A. Nargileh (water-pipe) smoking and incident coronary heart disease: a case-control study. Ann Epidemiol. 2001;8:570.

31. Kiter G, Ucan ES, Ceylan E, Kilinc O. Water-pipe smoking and pulmonary functions. Respir Med. 2000;94(9):891-894.

32. Villanti A, Cobb C, Cohn A, Williams V, Rath J. Correlates of hookah use and predictors of hookah trial in US young adults. Am J Prev Med. 2015;48(6):742-746. 
33. Akl E, Jawad M, Lam W, Co C, Obeid R, Irani J. Motives, beliefs and attitudes towards waterpipe tobacco smoking: a systematic review. Harm Redut J. 2013;10:12.

34. Myslin M, Zhu SH, Chapman W, Conway M. Using Twitter to examine smoking behavior and perceptions of emerging tobacco products. J Med Internet Res. 2013;15(8):e174.

35. Salloum R, Thrasher J, Kates F, Maziak W. Water pipe tobacco smoking in the United States: findings from the National Adult Tobacco Survey. Prev Med. 2015;71:88-93.

36. Jain S, Zhu SH, Conway M. Exploring consumer attitudes towards hookah, cigarettes, and cigars using Twitter. Tob Reg Sci. [In Press].

37. Creamer MR, Perry CL, Harrell MB, Diamond PM. Trends in multiple tobacco product use among high school students. Tob Reg Sci. [In Press].

38. Jamil HE, Elsouhaq D, Hiller S, Arnetz JE, Arnetz BB. Sociodemographic risk indicators of hookah smoking among white Americans: a pilot study. Nicotine Tob Res. 2010;12(5):525-529.

39. Centers for Disease Control and Prevention. The Health Consequences of Involuntary Exposure to Tobacco Smoke; 2006. Available from: surgeongeneral.gov/library/reports/secondhandsmoke/fullreport.pdf. Accessed June 6, 2015.

40. US Food and Drug Administration (FDA). FDA News Release. FDA proposes to extend its tobacco authority to additional tobacco products, including e-cigarettes. Washington, DC: FDA; 2014.

41. Centers for Disease Control and Prevention. The Dangers of Hookah Smoking; 2015. Available from: http://www.cdc.gov/features/ hookahsmoking/. Accessed May 23, 2015.

42. World Health Organization. Waterpipe Tobacco Smoking: Health Effects, Research Needs and Recommended Actions by Regulators. Tob Reg. 2005:1-11. Available from: http://www.who.int/tobacco/global_interaction/tobreg/waterpipe/en/. Accessed June 6, 2015.

43. Primack BA, Hopkins M, Hallett C, et al. US health policy related to hookah tobacco smoking. Am J Public Health. 2012;102(9): e47-e51.

44. Alabama Clean Indoor Act. Available from: https:/www.adph.org/tpts/ assets/S126.pdf. Accessed February 5, 2015.

45. Alaska Legislation. Available from: http://www.legis.state.ak.us/ basis/folioproxy.asp?url=http:/wwwjnu01.legis.state.ak.us/cgi-bin/ folioisa.dl1/stattx 12/query=*/doc/\%7bt8695\%7d. Accessed February 5, 2015.

46. Smokefree Arizona Act. Available from: http://www.azleg.gov/ ars/36/00601-01.htm. Accessed February 5, 2015.

47. Arkansas Clean Indoor Air Act. Available from: http:/www.healthy. arkansas.gov/programsServices/environmentalHealth/arcleanair/ Documents/rules/act8.pdf. Accessed February 1, 2015.

48. California Health and Safety Code. Available from: http://www. leginfo.ca.gov/cgi-bin/displaycode? section=hsc\&group $=118001$ 119000\&file=118875-118915. Accessed February 1, 2015.

49. Colorado Health and Environment. Available from: http://www.fda.gov/ downloads/AdvisoryCommittees/CommitteesMeetingMaterials/TobaccoProductsScientificAdvisoryCommittee/UCM287433.pdf. Accessed February 1, 2015.

50. Connecticut Laws and Regulations. Available from: http://www.cga. ct.gov/2011/rpt/2011-R-0118.htm. Accessed April 15, 2015.

51. Clean Indoor Air Act. Available from: http://delcode.delaware.gov/ title16/c029/. Accessed January 25, 2015.

52. Restrictions on Tobacco Smoking. Available from: http://dccode.org/ simple/Title-7/Chapter-17/. Accessed January 25, 2015.

53. The 2014 Florida Statutes. Available from: http://www.leg.state.fl.us/ Statutes/index.cfm?App_mode=Display_Statute\&URL=0300-0399/ 0386/0386.html. Accessed January 25, 2015.

54. Georgia Smokefree Air Act. Available from: http://www.georgialibraries. org/lib/library_laws/052013/31-12A-1\%20-\%2031-12A-13\%20 Ga.\%20Smokefree\%20Air\%20Act.pdf. Accessed January 25, 2015.

55. Hawaii Government. Available from: http:/www.capitol.hawaii.gov/ hrscurrent/Vol06_Ch0321-0344/HRS0328J/HRS_0328J-0001.htm. Accessed January 25, 2015.
56. Idaho Statutes. Available from: http://legislature.idaho.gov/idstat/ Title39/T39CH55.htm. Accessed January 25, 2015.

57. Illinois General Assembly. Available from: http:/www.ilga.gov/ LEGISLATION/ILCS/ilcs3.asp?ActID $=2893 \&$ ChapAct $=410 \% 26 \mathrm{nb}$ sp $\% 3$ BILCS $\% 26$ nbsp $\% 3$ B $82 \% 2 F \&$ ChapterID $=35 \&$ ChapterName $=P$ UBLIC+HEALTH\&ActName $=$ Smoke+Free+Illinois+Act. Accessed January 25, 2015.

58. House Enrolled Act. Available from: http://www.in.gov/legislative/ bills/2012/HE/HE1149.1.html. Accessed January 25, 2015.

59. Iowa Code 142D. The Smokefree Air Act. Available from: http://www. iowasmokefreeair.gov/common/pdf/iowacode142D.pdf. Accessed January $25,2015$.

60. Kansas Legislature. Available from: http://kslegislature.org/ 1i_2012/b2011_12/statute/021_000_0000_chapter/021_061_0000_ article/021_061_0009_section/021_061_0009_k/. Accessed January 25,2015 .

61. Kentucky Legislature. Available from: http://www.1rc.ky.gov/ record/11RS/HB193.htm. Accessed January 25, 2015.

62. Louisiana Smokefree Policy. Available from: http://new.dhh.louisiana. gov/index.cfm/page/609. Accessed February 1, 2015.

63. Maine Revised Statutes. Available from: http://legislature.maine.gov/ statutes/22/title22ch262sec0.html. Accessed February 1, 2015.

64. Maryland Regulations Scope. Available from: http://phpa.dhmh. maryland.gov/OEHFP/EH/Shared\%20Documents/CIAA_regulations. pdf. Accessed February 1, 2015.

65. The Commonwealth of Massachusetts. Available from: https:// malegislature.gov/Laws/GeneralLaws/PartIV/TitleI/Chapter270/ Section22. Accessed February 1, 2015.

66. Michigan Legislature: Clean Indoor Air Act. Available from: http://www. legislature.mi.gov/(S(4v5lrf45vpjwdq55skuy1r55))/mileg.aspx?page=L oadVirtualDoc\&BookmarkID=6497. Accessed February 1, 2015.

67. Clean Indoor Air Act. Available from: http://www.health.state.mn.us/ divs/eh/indoorair/mciaa/ftb/mciaa.pdf. Accessed February 1, 2015.

68. Senate Ammendments to HB 123. Available from: http://billstatus. 1s.state.ms.us/documents/2006/pdf/sam/Amendment_Report_for_ HB0123.pdf. Accessed February 1, 2015.

69. Missouri Revised Statutes. Available from: http://health.mo.gov/living/ wellness/tobacco/smokingandtobacco/pdf/Missouri_CIA_Statutes.pdf. Accessed February 1, 2015.

70. Montana Clean Indoor Air Act. Available from: http://leg.mt.gov/bills/ mca_toc/50_40_1.htm. Accessed February 1, 2015.

71. Nebraska Clean Indoor Air Act. Available from: http://dhhs.ne.gov/ publichealth/Documents/CIAA08.pdf. Accessed February 1, 2015.

72. Nevada Clean Indoor Air Act. Available from: https://www.leg.state.nv.us/ NRS/NRS-202.html\#NRS202Sec2485. Accessed February 1, 2015.

73. New Hampshire Statutes. Available from: http://www.gencourt.state.nh.us/ rsa/html/NHTOC/NHTOC-XII-155.htm. Accessed February 1, 2015.

74. State of New Jersey Legislature. Available from: http:/www.nj.gov/ health/ctcp/smokefree/documents/nj_smokefree_air_act.pdf. Accessed February 1, 2015.

75. New Mexico Clean Indoor Air Act. Available from: http://www. smokefreenm.com/images/uploads/HB0283GUS_3_1.pdf. Accessed February 1, 2015.

76. Regulation of Smoking in Public and Workplaces. Available from: https://www.health.ny.gov/regulations/public_health_law/section/1399/. Accessed February 1, 2015.

77. North Carolina Legislation Article 23. Available from: http://www. ncga.state.nc.us/EnactedLegislation/Statutes/HTML/ByArticle/ Chapter_130A/Article_23.html. Accessed February 1, 2015.

78. North Dakota Public Health Provisions. Available from: http:/www. ndhealth.gov/tobacco/ndcc_23-12.pdf. Accessed February 1, 2015.

79. Ohio Department of Health. Available from: http:/www.odh.ohio.gov/ rules/final/3701-50-59/f3701-52.aspx. Accessed February 1, 2015.

80. Oklahoma Statutes on Smoking in Public Places and Indoor Workplaces. Available from: http://www.ok.gov/breatheeasyok/documents/Okla homa $\% 20$ Laws $\% 20$ on $\% 20$ Secondhand $\% 20$ Smoke $\% 20$ effective $\% 20$ Nov\%201\%202010.pdf. Accessed February 1, 2015. 
81. Oregon Laws. Available from: http://www.oregonlaws.org/ors/433.845. Accessed February 1, 2015.

82. Pennsylvania Senate Bill. Available from: http://www.legis.state.pa.us/ CFDOCS/Legis/PN/Public/btCheck.cfm?txtType=HTM\&sessYr=2 007\&sessInd $=0 \&$ billBody $=$ S\&billTyp $=B \& b i l l N b r=0246 \& p n=2099$. Accessed February 1, 2015.

83. Health and Safety. Available from: http://webserver.rilin.state.ri.us/Statutes/ TITLE23/23-20.10/23-20.10-2.HTM. Accessed February 1, 2015.

84. South Carolina Code of Laws. Available from: http://www.scstatehouse gov/code/t44c095.php. Accessed February 1, 2015.

85. South Dakota Legislature. Available from: http://legis.sd.gov/Statutes/ Codified_Laws/DisplayStatute.aspx?Type=Statute $\&$ Statute $=34-46-$ 1\&cookieCheck=true. Accessed February 1, 2015.

86. Public Act. Available from: http://tennessee.gov/sos/acts/105/pub/ pc0410.pdf. Accessed February 1, 2015.

87. Texas Penal Code. Available from: http://www.statutes.legis.state.tx.us/ Docs/PE/htm/PE.48.htm. Accessed February 1, 2015.

88. Utah Indoor Clean Air Act. Available from: http://le.utah.gov/xcode/ Title26/Chapter38/26-38.html?v=C26-38_1800010118000101. Accessed February 1, 2015.

89. Vermont's Smokefree Laws. Available from: http://healthvermont.gov/ prevent/tobacco/restrictions_law.aspx. Accessed June 8, 2015.

90. Virginia Indoor Clean Air Act. Available from: http://leg1.state.va.us/ cgi-bin/legp504.exe?091+ful+SB1105S2+pdf. Accessed February 1, 2015.

91. Washington State Legislature. Available from: http://apps.leg.wa.gov/ rcw/default.aspx?cite=70.160\&full=true. Accessed February 1, 2015.
92. West Virginia Legislature. Available from: http://www.legis.state.wv.us/ wvcode/Code.cfm?chap=16\&art=9A. Accessed February 1, 2015.

93. Wisconsin State Legislature. Available from: http://docs.legis.wisconsin. gov/statutes/statutes/101///123. Accessed February 1, 2015.

94. Wyoming Sale of Tobacco. Available from: http://legisweb.state.wy.us/ statutes/statutes.aspx?file=titles/Title14/T14CH3AR3.htm. Accessed February 1, 2015.

95. Shihadeh A, Schubert J, Klaiany J, El Sabban M, Luch A, Saliba N. Toxicant content, physical properties and biological activity of waterpipe. Tob Control. 2015;24(Suppl 1):i22-i30.

96. American Lung Association. Hookah Smoking: A Growing Threat to Public Health. n.d.: 1-7. Available from: http://www.lung.org/ stop-smoking/tobacco-control-advocacy/reports-resources/cessationeconomic-benefits/reports/hookah-policy-brief.pdf. Accessed May 23, 2015.

97. Cobb C, Ward KD, Maziak W, Shihadeh AL, Eissenberg T. Waterpipe tobacco smoking: an emerging health crisis in the United States. $\mathrm{Am}$ J Health Behav. 2010;34:275-285.

98. Public Health Law Center. Hookah; 2010. Available from: http:// publichealthlawcenter.org/topics/tobacco-control/sales-restrictions/ hookah. Accessed August 12, 2015.

99. Maher J, Morris D, Girard K, Pizacani B. Consequences of clean indoor air exemptions in Oregon: the hookah story. Tob Control. 2014;23(3): 195-196.

100. Morris D, Fiala S, Pawlak R. Opportunities for policy interventions to reduce youth hookah smoking in the United States. Prev Chronic Dis. 2012;9:120082.
Risk Management and Healthcare Policy

\section{Publish your work in this journal}

Risk Management and Healthcare Policy is an international, peerreviewed, open access journal focusing on all aspects of public health, policy, and preventative measures to promote good health and improve morbidity and mortality in the population. The journal welcomes submitted papers covering original research, basic science, clinical \& epidemio-

\section{Dovepress}

logical studies, reviews and evaluations, guidelines, expert opinion and commentary, case reports and extended reports. The manuscript management system is completely online and includes a very quick and fair peerreview system, which is all easy to use. Visit http://www.dovepress.com/ testimonials.php to read real quotes from published authors. 